\section{RMD Open}

Rheumatic \&

Musculoskeletal Diseases

\title{
Polymyalgia rheumatica: an autoinflammatory disorder?
}

\author{
Alberto Floris, ${ }^{1}$ Matteo Piga, ${ }^{1}$ Alberto Cauli, ${ }^{1}$ Carlo Salvarani, ${ }^{2,3}$ \\ Alessandro Mathieu ${ }^{1}$
}

To cite: Floris A, Piga M, Cauli A, et al. Polymyalgia rheumatica: an autoinflammatory disorder?. RMD Open 2018;4:e000694. doi:10.1136/ rmdopen-2018-000694

- Prepublication history for this paper is available online. To view these files, please visit the journal online (http://dx.doi. org/10.1136/rmdopen-2018000694).

Received 4 April 2018 Accepted 8 May 2018

\section{Check for updates}

${ }^{1}$ Rheumatology and Rheumatology Unit, University Clinic AOU of Cagliari, Cagliari, Italy

${ }^{2}$ Rheumatology and Rheumatology Unit, Università d Modena e Reggio Emilia, Reggio Emilia, Italy

${ }^{3}$ Azienda USL-IRCCS di Reggio Emilia, Reggio Emilia, Italy

Correspondence to Dr Alberto Floris; albertofloris1@gmail.com
Polymyalgia rheumatica (PMR) is an elderly onset syndrome characterised by aching and stiffness in the shoulders and the pelvic girdle associated to increased levels of acute phase reactants and rapid response to glucocorticoids. ${ }^{1}$ Although the cause of PMR remains unknown, most of the evidence suggest a multifactorial aetiology inducing an immunomediated pathogenesis. ${ }^{12}$

According to the 'immunological continuum model' proposed by McGonagle in 2006, all immune-mediated diseases can be conceptualised as predominantly autoinflammatory, predominantly autoimmune or mixed, on the basis of the relative contributions of innate and adaptive immune responses. ${ }^{3} \quad$ Autoinflammatory diseases (AIDs) are characterised by tissue inflammation mainly due to aberrant activation of innate immune system without autoantibodies production and autoreactive $\mathrm{T}$ lymphocyte activation. In contrast, autoimmune diseases (ADs) are typically depicted by an abnormal activation of the adaptive immune system. ${ }^{4}$ However, the emerging understanding of the close linkage between innate and adaptive immunity led to consider the rare monogenic AIDs and ADs as the two opposite ends into a continuum of immune-mediated disorders, where middle entities are recognised (figure 1). ${ }^{3}$

In the view of this background, we tried to envisage the most suitable place for PMR into the spectrum of the autoinflammatory/autoimmune disorders by reviewing and interpreting current evidence.

Clear indication for a prevalent autoinflammatory background of PMR is related to the disease onset and course. Actually, starting of symptoms is generally over a few days or overnight in PMR, ${ }^{1}$ as well as in inflammatory periodic-recurring occurrence of AIDs, ${ }^{5}$ but in contrast to classic polygenic ADs where a subacute onset is frequently recorded (figure 2A) ${ }^{6}$ Further, after low-dose glucocorticoid therapy initiation, patients with PMR experience a rapid improvement of symptoms, generally within 24-72 hours, and more than $40 \%$ of them achieve complete response within 3 weeks. ${ }^{1}$ Similarly, in rare monogenic AIDs, a rapid remission of symptoms and significant reduction in frequency of inflammatory attacks is rapidly achieved with specific treatment, such as colchicine in familial Mediterranean fever (FMF) and interleukin-1 $\beta$ (IL-1 $\beta$ ) blockade in cryopyrin-associated periodic syndrome. ${ }^{7}$ Conversely, a chronic or relapsing-remitting course, with a minimal residual disease activity and progressive damage accrual, is frequently recorded in ADs (figure 2B). ${ }^{8}$

Age of onset and gender distribution are inconclusive in discriminating the prevalent autoinflammatory or autoimmune nature of PMR (figure 2C). Indeed, both in ADs and AIDs elderly onset is rare, and the main determinant of the onset age is the monogenic (childhood) or polygenic (adulthood) nature of the disease. ${ }^{49}$ Further, the preferential involvement of woman in PMR (female to male ratio $=2: 1$ ) seems related to a different and currently unknown mechanism than the arise in oestrogen production reported as one of the main determinants of the female prevalence in typical ADs, such as systemic lupus erythematosus (SLE) (female to male ratio $=9: 1) .{ }^{19}$

Laboratory findings lean towards a predominant role of innate immune response in PMR. Indeed, a remarkable increase of inflammatory markers is one of the most consistent features in patients with both PMR and AIDs, so that it is included into the diagnostic criteria and monitoring parameters for both conditions. ${ }^{17}$ Increase of acute phase reactants can also occur in ADs, but with lower frequency and diagnostic accuracy (figure 2D) ${ }^{4}$ Further, autoantibodies carrying 


\begin{tabular}{|c|c|c|c|c|}
\hline \multicolumn{2}{|c|}{ Autoinflammatory diseases (AIDs) } & \multirow{2}{*}{$\begin{array}{c}\text { Mixed } \\
\text { Polygenic }\end{array}$} & \multicolumn{2}{|c|}{ Autoimmune diseases (ADs) } \\
\hline Monogenic & Polygenic & & Polygenic & Monogenic \\
\hline FMF & Crohn disease & Ankylosing spondylitis & SLE & APS \\
\hline CAPS & Gout & Psoriatic arthritis & SS & IPEX \\
\hline HIDS & Behçet disease & & SSc & ALPS \\
\hline TRAPS & sJIA & & $\begin{array}{r}\text { PM/DM } \\
\text { MCTD }\end{array}$ & \\
\hline
\end{tabular}

In the chromatic bar, red (left side), yellow (central) and green (right side) represent the continuum of autoinflammatory, mixed and autoimmune diseases. FMF: Familial Mediterranean fever; CAPS: cryopyrin-associated periodic syndrome; HIDS: hyper-immunoglobulinemia D syndrome; TRAPS: TNF receptor-associated periodic syndrome; sJIA: systemic juvenile idiopathic arthritis; SLE: systemic lupus erythematosus; SSc: systemic sclerosis; SS: Sjögren'syndrome; PM/DM: polymyositis and dermatomyositis; MCTD: mixed connective tissue diseases; APS: autoimmune polyendocrinopathy syndrome; IPEX: immune-dysregulation polyendocrinopathy enteropathy X-linked syndrome; ALPS: autoimmune lymphoproliferative syndrome.

Figure 1 Simplified classification of immune-mediated disease by McGonagle and McDermott. ${ }^{3}$

a significant pathogenic and/or diagnostic role have not been identified in PMR, as well as in AIDs, ${ }^{4}$ whereas they are frequently associated to prototypical $\mathrm{ADs}$ (eg, antidouble-stranded DNA in SLE, anti-citrullinated peptide in rheumatoid arthritis (RA)) (figure 2E). ${ }^{410}$ Noteworthy, lack of pathogenetic autoantibodies is typically recorded in other immune-mediated diseases, such as the major histocompatibility complex class I (MHC-I)-pathies (eg, ankylosing spondylitis, psoriatic arthritis) that are reported as prototypical mixed autoinflammatory/autoimmune disorders in the immunological continuum. ${ }^{3}$

Similar to AIDs and in contrast to what is reported for typical ADs, not significant overlap has been identified between PMR and other immunological disorders, excepting for giant cell arteritis (GCA).$^{11}$ However, it is still unclear whether GCA represents a separate condition from PMR or a potential expression of the same disease (figure 2). ${ }^{3} 12$ Further, a mixed contribution of innate and adaptive immunity, supported by the bringing function of Th17 cells, has been recognised in the GCA. ${ }^{1}$

Despite the widely incomplete knowledge on pathogenesis of PMR, some suggestions for a predominant autoinflammatory nature of the disease arise from the genetic background and cytokine profile. Indeed, a clear association between human leukocyte antigen (HLA) class II alleles (especially HLA-DRB1*0401) and isolated PMR has not been definitely demonstrated due to conflicting data from different populations. ${ }^{1}$ On the other hand, HLA class II alleles have been found to associate with GCA susceptibility and GCA with PMR symptoms, as well as in most of ADs (figure 2G) ${ }^{13-15}$ Polymorphisms of additional genes involved in initiating and regulating inflammatory response, such as intercellular adhesion molecule-1, tumour necrosis factor (TNF), interleukin 6 (IL-6) and interleukin 1 (IL-1) receptor antagonist (IL-1RN) have also been identified as possible susceptibility factors for PMR. ${ }^{16}$ Interestingly, Alvarez-Rodriguez reported that the IL-1RN*2 polymorphism in a homozygous state associated to higher susceptibility to PMR when compared with healthy controls and GCA, as well as to elderly onset RA (EORA) when compared with youngonset RA. ${ }^{15}$
Regarding the cytokine profile, evidence of a IL-6 central pathophysiological role in PMR has been provided. Remarkably, among rheumatic diseases, the highest serum levels of IL-6 were found in patients affected by PMR and GCA $^{17}$ as well as in EORA. ${ }^{18}$ The latter presents some not canonical features compared with traditional ADs (eg, lower prevalence of autoantibodies, reduced prevalence in females, less straight association with HLA-II) and might be part of an autoinflammatoryautoimmune mixed subtype of RA. ${ }^{19}$ Further, in contrast to several ADs, increased levels of serum interferon- $\gamma$ (IFN- $\gamma$ ) were not found in PMR. Moreover, IFN- $\gamma$ was observed in the temporal artery biopsy (TAB) specimens of GCA patients, while it was not seen in TAB of patients with isolated PMR, suggesting a key role of this cytokine in the progression to overt arteritis. ${ }^{20}$ Finally, increased level of circulating type I IFN has not been reported neither on PMR and $\mathrm{GCA}^{21}$ and no data are currently available on type I IFN signature, which is considered an hallmark of several ADs (figure 2H).

Further pathobiological findings supporting the key role of innate immunity in PMR pathogenesis are represented by the increased expression of toll-like receptor (TLR)-7 and TLR-9 in peripheral blood monocytic cells and the emerging involvement of Th17 cells. ${ }^{22}$

To date, glucocorticoids remain the cornerstone of treatment for PMR, whereas poor evidence is available on the effectiveness of traditional immunosuppressants. Methotrexate (MTX) is the most used glucocorticoid-sparing agent in PMR, although randomised controlled trials data on relapse rate and cumulative glucocorticoid dose reduction are conflicting. ${ }^{23}$ Potential benefit of MTX may be related to antinflammatory effects, resulting from reduced monocytic cell activation, decreased IL-1 and IL-6 secretion, as well as from inhibition of cyclo-oxygenases synthesis, neutrophil chemotaxis and adhesion molecules expression. ${ }^{24}$ Traditional immunosuppressants are generally not used in AIDs because of the poor effectiveness in the management of attacks and prevention of relapse. ${ }^{725}$ Conversely, traditional immunosuppressants are the first-line treatment in most of ADs, while glucocorticoids can be associated 


\begin{tabular}{|c|c|c|c|c|}
\hline & & In typical AIDs & In PMR & In typical ADs \\
\hline & Disease onset & & 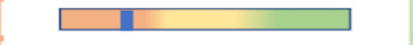 & \\
\hline & & $\begin{array}{l}\text { Acute / hyper-acute onset of } \\
\text { recurring inflammatory attacks. }\end{array}$ & $\begin{array}{l}\text { Onset of symptoms is generally } \\
\text { over a few days or overnight. }\end{array}$ & $\begin{array}{l}\text { Frequent subacute onset in most of } \\
\text { ADs. }\end{array}$ \\
\hline \multirow[t]{2}{*}{ b. } & Disease course & & 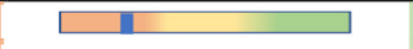 & \\
\hline & & $\begin{array}{l}\text { Rapid remission is frequently } \\
\text { achieved with specific treatment, } \\
\text { such as colchicine in FMF or anti- } \\
\text { IL } 1 \beta \text { blockade in CAPS. }\end{array}$ & $\begin{array}{l}\text { Rapid improvement of symptoms, } \\
\text { generally within } 24-72 \text { hours, with } \\
\text { complete response achieved in } \\
\geq 40 \% \text { within } 3 \text { weeks. }\end{array}$ & $\begin{array}{l}\text { Frequent chronic or relapsing- } \\
\text { remitting course, with minimal } \\
\text { residual disease activity and } \\
\text { progressive damage accrual. }\end{array}$ \\
\hline \multirow[t]{2}{*}{ c. } & Onset age and & & \begin{tabular}{|l|l|}
$\square$ \\
\end{tabular} & \\
\hline & $\begin{array}{l}\text { gender } \\
\text { distribution }\end{array}$ & $\begin{array}{l}\text { Monogenic in infancy; polygenic } \\
\text { usually in the adulthood, without } \\
\text { gender prevalence. Rare in elderly. }\end{array}$ & $\begin{array}{l}\text { Exclusively in people }>50 \text { years } \\
\text { (peak incidence }>65 \mathrm{yrs} \text { ). Two third } \\
\text { of patients are woman. }\end{array}$ & $\begin{array}{l}\text { Monogenic in infancy; polygenic } \\
\text { more frequent in woman in } \\
\text { childbearing age. Rare in elderly. }\end{array}$ \\
\hline \multirow[t]{2}{*}{ d. } & Acute phase & & 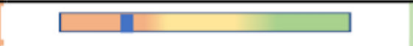 & \\
\hline & reactants & $\begin{array}{l}\text { Remarkable increase of acute } \\
\text { phase reactants in most of AIDs. }\end{array}$ & $\begin{array}{l}\text { Remarkable increase of acute } \\
\text { phase reactants great majority of } \\
\text { patients. }\end{array}$ & $\begin{array}{l}\text { Increase also in several ADs, but } \\
\text { with lower diagnostic accuracy } \\
\text { than AIDs. }\end{array}$ \\
\hline e. & Autoantibodies & & 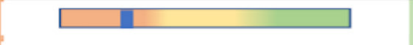 & \\
\hline & & $\begin{array}{l}\text { No autoantibodies with significant } \\
\text { diagnostic and/or pathogenic role. }\end{array}$ & $\begin{array}{l}\text { No autoantibodies with significant } \\
\text { diagnostic and/or pathogenic role. }\end{array}$ & $\begin{array}{l}\text { Frequent presence of autoantibo- } \\
\text { dies with significant pathogenic } \\
\text { and diagnostic role (e.g. anti- } \\
\text { dsDNA and anti-Sm in SLE). }\end{array}$ \\
\hline \multirow[t]{2}{*}{ f. } & Overlap with & & 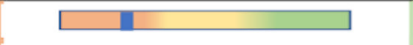 & \\
\hline & $\begin{array}{l}\text { other } \\
\text { immunological } \\
\text { disease }\end{array}$ & $\begin{array}{l}\text { No significant overlap with other } \\
\text { immune-mediated diseases. }\end{array}$ & $\begin{array}{l}\text { No significant overlap has been } \\
\text { identified between PMR and other } \\
\text { immune-mediated diseases, } \\
\text { excepting for GCA. }\end{array}$ & $\begin{array}{l}\text { ADs frequently overlap with each } \\
\text { other. }\end{array}$ \\
\hline \multirow[t]{2}{*}{ g. } & Genetic & & $\square$ & \\
\hline & background & Not as sociated to HLA class II. & $\begin{array}{l}\text { Conflicting data on association to } \\
\text { HLA-II alleles. Polymorphisms of } \\
\text { genes involved in the initiation and } \\
\text { regulation of inflammatory (e.g. } \\
\text { ICAM-1, TNF, IL-1 } \beta \text {, RANTES, IL-6) }\end{array}$ & $\begin{array}{l}\text { HLA region (especially class II) is } \\
\text { among the strongest genetic risk } \\
\text { factors for most of ADs. }\end{array}$ \\
\hline & Cytokine profile & & \begin{tabular}{l|l|l|}
$\square$ \\
$\square$
\end{tabular} & \\
\hline & & $\begin{array}{l}\text { Pivotal role of IL- } 1 \beta \text {. Increased } \\
\text { levels of IL- } 6 \text { in several AIDs, such } \\
\text { as FMF, HIDS, TRAPS, Behçet. No } \\
\text { evidences of IFNs involvement. }\end{array}$ & $\begin{array}{l}\text { Pivotal role of IL- } 6 \text {. Increased } \\
\text { expression of IL- } 1 \beta \text { in interstitial } \\
\text { muscle tissue. No increase level of } \\
\text { type I e II IFNs. }\end{array}$ & $\begin{array}{l}\text { A common cytokine not identifies. } \\
\text { Highest circulating IL- } 6 \text { in elderly } \\
\text { onset RA. A significant activation } \\
\text { IFN genes in SLE, DM, PM, RA, SS. }\end{array}$ \\
\hline \multirow[t]{2}{*}{ i. } & Traditional & & $\square$ & \\
\hline & $\begin{array}{l}\text { immunosup- } \\
\text { pressants (tIS) }\end{array}$ & $\begin{array}{l}\text { tIS generally not used because the } \\
\text { poor evidence of their } \\
\text { effectiveness in management of } \\
\text { attacks and prevention of relapses. }\end{array}$ & $\begin{array}{l}\text { GC cornerstone of therapy. } \\
\text { Conflicting data on effectiveness of } \\
\text { tIS as steroid-sparing agents. } \\
\text { Conflicting data also on MTX, } \\
\text { which benefits may be from its } \\
\text { autoinflammatory effect. }\end{array}$ & $\begin{array}{l}\text { tIS are the cornerstone in } \\
\text { treatment of the majority of ADs, } \\
\text { having a disease-modifying effects. } \\
\mathrm{GC} \text { are considered as adjuvants. }\end{array}$ \\
\hline & Biological & & 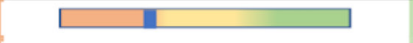 & \\
\hline & $\begin{array}{l}\text { immunosup- } \\
\text { pressants (bIS) }\end{array}$ & $\begin{array}{l}\text { Anti-IL6R and anti-IL- } 1 \beta \text { effective in } \\
\text { treatment of several mono- and } \\
\text { polygenic AIDs. Anti-TNF used in } \\
\text { several AIDs, but not as a first line } \\
\text { treatment. }\end{array}$ & $\begin{array}{l}\text { Promising data on use of anti-IL6R. } \\
\text { Poor data on anti-IL-1 } 1 \beta \text {. Anti-TNF } \\
\text { ineffective and potentially harmful. } \\
\text { PMR not reported as paradoxical } \\
\text { effect of anti-TNF. }\end{array}$ & $\begin{array}{l}\text { Anti-IL6R and anti-IL- } 1 \beta \text { approved } \\
\text { for treatment of RA. Use of anti- } \\
\text { TNF in several ADs limited by the } \\
\text { risk of paradoxical induction } \\
\text { immunological disorders. }\end{array}$ \\
\hline
\end{tabular}

Features of prototypical autoinflammatory (AIDs) and autoimmune diseases (ADs) are reported in the red (left side) and green (right side) column, respectively; in the central chromatic bar the position of the vertical line represents the affinity level of polymyalgia meumatica (PMR) with AIDs or AIDs, in regards of the disease aspect examined in the respective row.

FMF: familial Mediterranean fever; CAPS: cryopyrin-associated periodic syndrome; SLE: systemic lupus erythematosus; GCA: giant cell arteritis; PM: polymyositis; DM: dermatomyositis; RA: rheumatoid arthritis; SS: Sjögren's syndrome; IL-1 $\beta$ : interleukin-1 $\beta$; IL-6: interleukin-6; ICAM-1: intercelluar adhesion molecule-1; TNF: tumor necrosis factor; RANTES: regulated on activation, normal T cell expressed and secreted; IFN: interferon; tIS: traditional immunosuppressants; bIS: biological immunosuppressants; MTX: methotrexate

Figure 2 Summary of our interpretation of scientific data on polymyalgia rheumatica, in the view of its classification in the spectrum of immune-mediated diseases. 
as adjuvant therapy, especially in the induction phase of the treatment (figure 2I) ${ }^{26}$

Experience from patients with PMR symptoms in GCA and data from an open-label uncontrolled study on 20 subjects with isolated PMR suggest anti-IL-6R therapy as an effective option in reducing Disease Activity Score and reducing cumulative exposition to glucocorticoids (glucocorticoid-sparing effect at 24 weeks is $70.2 \%) .{ }^{27}$ AntiIL-6R also showed promising results in several AIDs, such as systemic juvenile idiopathic arthritis, Behçet disease, FMF and TNF receptor-associated periodic syndrome. ${ }^{28}$ Most of current data on anti-TNF treatment suggest it is ineffective, expensive and potentially harmful in patients with PMR. ${ }^{1}$ Positive results in terms of effectiveness were detected for connective tissue diseases and other ADs, but its use is limited by the observation of several cases of anti-TNF-induced autoimmune disorders. ${ }^{29}$ Interestingly, PMR is not reported among the immune-mediated paradoxical effect of anti-TNF (figure 2J). Data on anti-IL-1 $\beta$ are limited to a single blind study, where canakinumab was administered to three patients with new-onset PMR, with not conclusive results in terms of effectiveness. ${ }^{30}$ Therefore, further data from large trial on anti-IL-1 $\beta$ in PMR would be warranted.

In summary, despite the incomplete knowledge of PMR pathophysiology and the lack of validate discriminative criteria for polygenic AIDs, current evidence suggests that PMR does not easily fit into any of the two pure ends in the spectrum of the immune-mediated disorders, but a greater affinity for AIDs seems to emerge.

In our opinion, this interpretation of the available scientific data might represent an insight with a significant practical implication. Indeed, among the unmet needs in PMR, there is the availability of effective and safety therapeutic options for patients not adequately responsive or requiring longer exposition to glucocorticoids or with an unfavourable risk profile of steroid-related adverse effects. In this view, the recognition of predominantly autoinflammatory nature of PMR should address future research aimed to develop targeted therapies.

Contributors AM: conceived of the present idea. AF and MP: equally contributed to perform the literature review and draft the manuscript. All authors contributed to the interpretation of the recorded evidence. AC, CS and AM: critically reviewed the manuscript. All Authors approved the final version.

Funding The authors have not declared a specific grant for this research from any funding agency in the public, commercial or not-for-profit sectors.

Competing interests None declared.

Patient consent Not required.

Provenance and peer review Not commissioned; externally peer reviewed.

Open Access This is an Open Access article distributed in accordance with the Creative Commons Attribution Non Commercial (CC BY-NC 4.0) license, which permits others to distribute, remix, adapt, build upon this work non-commercially, and license their derivative works on different terms, provided the original work is properly cited and the use is non-commercial. See: http://creativecommons.org/ licenses/by-nc/4.0/

(c) Article author(s) (or their employer(s) unless otherwise stated in the text of the article) 2018. All rights reserved. No commercial use is permitted unless otherwise expressly granted.

\section{REFERENCES}

1. González-Gay MA, Matteson EL, Castañeda S. Polymyalgia rheumatica. The Lancet 2017;390:1700-12.

2. Pipitone N, Salvarani C. Update on polymyalgia rheumatica. Eur J Intern Med 2013;24:583-9.

3. McGonagle D, McDermott MF. A proposed classification of the immunological diseases. PLoS Med 2006;3:e297.

4. Doria A, Zen M, Bettio S, et al. Autoinflammation and autoimmunity: bridging the divide. Autoimmun Rev 2012;12:22-30.

5. Federici S, Sormani MP, Ozen S, et al. Evidence-based provisional clinical classification criteria for autoinflammatory periodic fevers. Ann Rheum Dis 2015;74:799-805.

6. Arbuckle MR, McClain MT, Rubertone MV, et al. Development of autoantibodies before the clinical onset of systemic lupus erythematosus. N Engl J Med 2003;349:1526-33.

7. ter Haar NM, Oswald M, Jeyaratnam J, et al. Recommendations for the management of autoinflammatory diseases. Ann Rheum Dis 2015;74:1636-44.

8. Barr SG, Zonana-Nacach A, Magder LS, et al. Patterns of disease activity in systemic lupus erythematosus. Arthritis Rheum 1999;42:2682-8.

9. Cooper GS, Stroehla BC. The epidemiology of autoimmune diseases. Autoimmun Rev 2003;2:119-25.

10. Floris A, Piga M, Cauli A, et al. Predictors of flares in systemic lupus erythematosus: preventive therapeutic intervention based on serial anti-dsDNA antibodies assessment. Analysis of a monocentric cohort and literature review. Autoimmun Rev 2016;15:656-63.

11. Chuang TY, Hunder GG, Ilstrup DM, et al. Polymyalgia rheumatica: a 10-year epidemiologic and clinical study. Ann Intern Med 1982;97:672-80.

12. Cantini F, Niccoli L, Storri L, et al. Are polymyalgia rheumatica and giant cell arteritis the same disease? Semin Arthritis Rheum 2004;33:294-301.

13. Fernando MM, Stevens CR, Walsh EC, et al. Defining the role of the MHC in autoimmunity: a review and pooled analysis. PLoS Genet 2008;4:e1000024.

14. Gonzalez-Gay MA. Genetic epidemiology. Giant cell arteritis and polymyalgia rheumatica. Arthritis Res 2001;3:154-7.

15. Dababneh A, Gonzalez-Gay MA, Garcia-Porrua C, et al. Giant cell arteritis and polymyalgia rheumatica can be differentiated by distinct patterns of HLA class II association. J Rheumatol 1998;25:2140-5.

16. Alvarez-Rodriguez L, Carrasco-Marin E, Lopez-Hoyos M, et al. Interleukin-1RN gene polymorphisms in elderly patients with rheumatic inflammatory chronic conditions: Association of IL$1 \mathrm{RN}^{*} 2 / 2$ genotype with polymyalgia rheumatica. Hum Immunol 2009;70:49-54.

17. Salvarani C, Cantini F, Niccoli L, et al. Acute-phase reactants and the risk of relapse/recurrence in polymyalgia rheumatica: a prospective followup study. Arthritis Rheum 2005;53:33-8.

18. Chen DY, Hsieh TY, Chen YM, et al. Proinflammatory cytokine profiles of patients with elderly-onset rheumatoid arthritis: a comparison with younger-onset disease. Gerontology 2009;55:250-8.

19. Savic S, Mistry A, Wilson AG, et al. Autoimmune-autoinflammatory rheumatoid arthritis overlaps: a rare but potentially important subgroup of diseases. RMD Open 2017;3:e000550.

20. Weyand CM, Hicok KC, Hunder GG, et al. Tissue cytokine patterns in patients with polymyalgia rheumatica and giant cell arteritis. Ann Intern Med 1994;121:484-91.

21. van der Geest KS, Abdulahad WH, Rutgers A, et al. Serum markers associated with disease activity in giant cell arteritis and polymyalgia rheumatica. Rheumatology 2015;54:1397-402.

22. Guggino G, Ferrante A, Macaluso F, et al. Pathogenesis of polymyalgia rheumatica. Reumatismo 2018;70:10-17.

23. Buttgereit F, Dejaco C, Matteson EL, et al. Polymyalgia rheumatica and giant cell arteritis: a systematic review. JAMA 2016;315:2442-58.

24. Cutolo M, Sulli A, Pizzorni C, et al. Anti-inflammatory mechanisms of methotrexate in rheumatoid arthritis. Ann Rheum Dis 2001;60:729-35.

25. Cantarini L, Lucherini OM, Muscari I, et al. Tumour necrosis factor receptor-associated periodic syndrome (TRAPS): state of the art and future perspectives. Autoimmun Rev 2012;12:38-43.

26. Duru N, van der Goes MC, Jacobs JW, et al. EULAR evidence-based and consensus-based recommendations on the management of medium to high-dose glucocorticoid therapy in rheumatic diseases. Ann Rheum Dis 2013;72:1905-13.

27. Devauchelle-Pensec V, Berthelot JM, Cornec D, et al. Efficacy of first-line tocilizumab therapy in early polymyalgia rheumatica: a prospective longitudinal study. Ann Rheum Dis 2016;75:1506-10. 
28. Tanaka T, Kishimoto T. Targeting interleukin-6: all the way to treat autoimmune and inflammatory diseases. Int $\mathrm{J}$ Biol Sci 2012;8:1227-36

29. Ramos-Casals M, Roberto-Perez-Alvarez, Diaz-Lagares C, et al. Autoimmune diseases induced by biological agents: a double-edged sword? Autoimmun Rev 2010;9:188-93.
30. Matteson EL, Dasgupta B, Schmidt WA. 2-Week single-blind, randomized, 3-arm proof of concept study of the effects of secukinumab (anti-IL17 mAb), canakinumab (anti-IL-1 b mAb), or corticosteroids on initial disease activity scores in patients with PMR, followed by an open-label extension to ssess safety and effect duration. Arthritis Rheum 2014;66(Suppl):391-2. 